discussion papers FÜR SOZIALFORSCHUNG

SOCIAL SCIENCE RESEARCH CENTER BERLIN

FS IV $02-17$

Taxation and Education Investment in the Tertiary Sector

Fredrik Andersson *

Kai A. Konrad **

* Lund University

** Wissenschaftszentrum Berlin für Sozialforschung

October 2002

ISSN Nr. 0722 - 6748

Forschungsschwerpunkt

Markt und politische Ökonomie

Research Area

Markets and Political Economy 
Zitierweise/Citation:

Fredrik Andersson, Kai A. Konrad, Taxation and Education Investment in the Tertiary Sector, Discussion Paper FS IV 02-17, Wissenschaftszentrum Berlin, 2002.

Wissenschaftszentrum Berlin für Sozialforschung gGmbH, Reichpietschufer 50, 10785 Berlin, Tel. (030) 25491 - 0 Internet: www.wz-berlin.de 


\title{
ABSTRACT
}

\section{Taxation and Education Investment in the Tertiary Sector}

\author{
by Fredrik Andersson and Kai A. Konrad
}

In this paper we briefly report some key data on educational expenditure and output in OECD countries and then turn to the motivations for public education. Public education can be important for equal opportunities and has a number of redistributional aspects within and between generations. We further discuss possible externalities of education, the issue of intersectoral investment neutrality and a fundamental time consistency problem of optimal taxation that may make public expenditure on tertiary education desirable from an efficiency point of view. Further we discuss whether and how globalization changes the picture. Mobility changes the analysis of optimal taxation and may make public expenditure less important. We also emphasize insurance aspects and the role of mobility differences.

Keywords: Taxation, education, human capital investment JEL classification: H21, H23

\footnotetext{
This paper will appear as chapter 13 in Alternatives for Welfare Policy, Cambridge University Press, edited by Torben Andersen and Per Molander. Financial support by SNS is gratefully acknowledged. We thank the participants of two workshops at Krusenberg, and in particular, Dennis Snower and Per Molander for very valuable comments and suggestions.
} 


\section{ZUSAMMENFASSUNG}

\section{Besteuerung und Bildungsinvestitionen im tertiären Sektor}

Wir berichten zunächst einige wesentliche Daten zu öffentlichen Ausgaben für Bildung in den OECD-Ländern und zu deren Wirkung. Im Zentrum der Arbeit steht eine Diskussion der unterschiedlichen Begründungen für öffentliche Bildungsinvestitionen. Zunächst wird auf die Argumente der Chancengleichheit und auf die intragenerationalen und intergenerationellen Umverteilungswirkungen von öffentlichen Bildungsinvestitionen eingegangen. Sodann wird das Zusammenspiel von Besteuerung und öffentlichen Bildungsinvestitionen problematisiert. Es zeigt sich, dass öffentliche Bildungsinvestitionen die staatliche Korrektur für eine Form von Staatsversagen sein können, das darin besteht, dass der Staat bei zeitkonsistenter optimaler Besteuerung Bildungsinvestitionen ex-post zu stark besteuert. Wir diskutieren ferner die Wirkungen der Globalisierung, besonders der zunehmenden Mobilität von Humankapitalträgern für die Frage öffentlicher Bildungsinvestitionen und konzentrieren uns dabei auf den Zusammenhang von Besteuerung und öffentlichen Bildungsausgaben. Mobilität kann das Zeitkonsistenzproblem lösen und kann einen der Gründe für öffentliche Bildungsinvestitionen eliminieren. $\mathrm{Zu}$ berücksichtigen sind zudem Versicherungsaspekte und der Aspekt von Mobilitätsunterschieden für verschiedene Berufsgruppen. 


\section{Introduction}

The public sector massively intervenes in the education sector in practically all OECD countries. Via free public provision of education, transfers to students, or high subsidies on education, the government strongly influences the private education decisions. Education has elements of investment and consumption. For an analysis of public education policy the investment aspects are more relevant, and in what follows we will concentrate on these aspects.

Expenditures on education goods - from private and public sources - were 5.75 percent of GDP on average in the OECD countries in 1998 (OECD 2001a, p. 80). The variation in total expenditures across OECD countries was modest, ranging from 3.5 percent of GDP in Turkey and 4.6 in the Netherlands, to 7.0 percent in Korea and 7.2 percent in Denmark.

The public sector carries the lion share of the costs of education in most OECD countries. In many countries primary and secondary education is financed almost exclusively by the public sector. An interesting fact is that the top group in terms of total expenditures includes countries with among the largest shares of public funding, like Sweden and Denmark, as well as countries with among the smallest public financing shares, like Korea and the US (cf. OECD 2001a, p. 93).

As has been illustrated by Carl Emmerson and Howard Reed (2002), roughly a fourth of the education-goods expenditures are made on tertiary education; the OECD average is 1.59 percent of GDP. It is important to note that the public-sector share seems to be larger in countries with higher income taxes. In fact, the correlation between the public-financing shares and the top marginal tax rates in 1998, is 0.42. This positive correlation is in line with the hypothesis that public education spending is - at least to some extent - a second-best response to a problem of time-consistent overtaxation of the returns on human capital; we will discuss the hypothesis below.

There are several possible measures of the outcome of education expenditures. A measure of the overall use of education - both as a consumption good and as an investment good - is the average total amount of (tertiary) education acquired. The number of years is roughly in line with the resources spent; the correlation between total expenditures and expected number of years is 0.70 .

A related measure of the output of the education system, often argued to be particularly relevant for the broader economic performance of a country, is the extent to which an education system produces workers with high skills in science and technology. Figure 1 shows the number of science graduates (per 100 000) in a number of countries; the mean is 1200 .

1 Public-sector shares from OECD (2001a, p. 81); marginal tax rates from OECD (2001b, pp. 38-39); countries for which either measure is unavailable are excluded.

2 Total expenditures from OECD (2001a, p. 81); expected number of years from OECD (2001a, p. 133); countries not reporting both are excluded. 
Figure 1: Number of science graduates per 100000 persons in the labour force 25-35 years of age

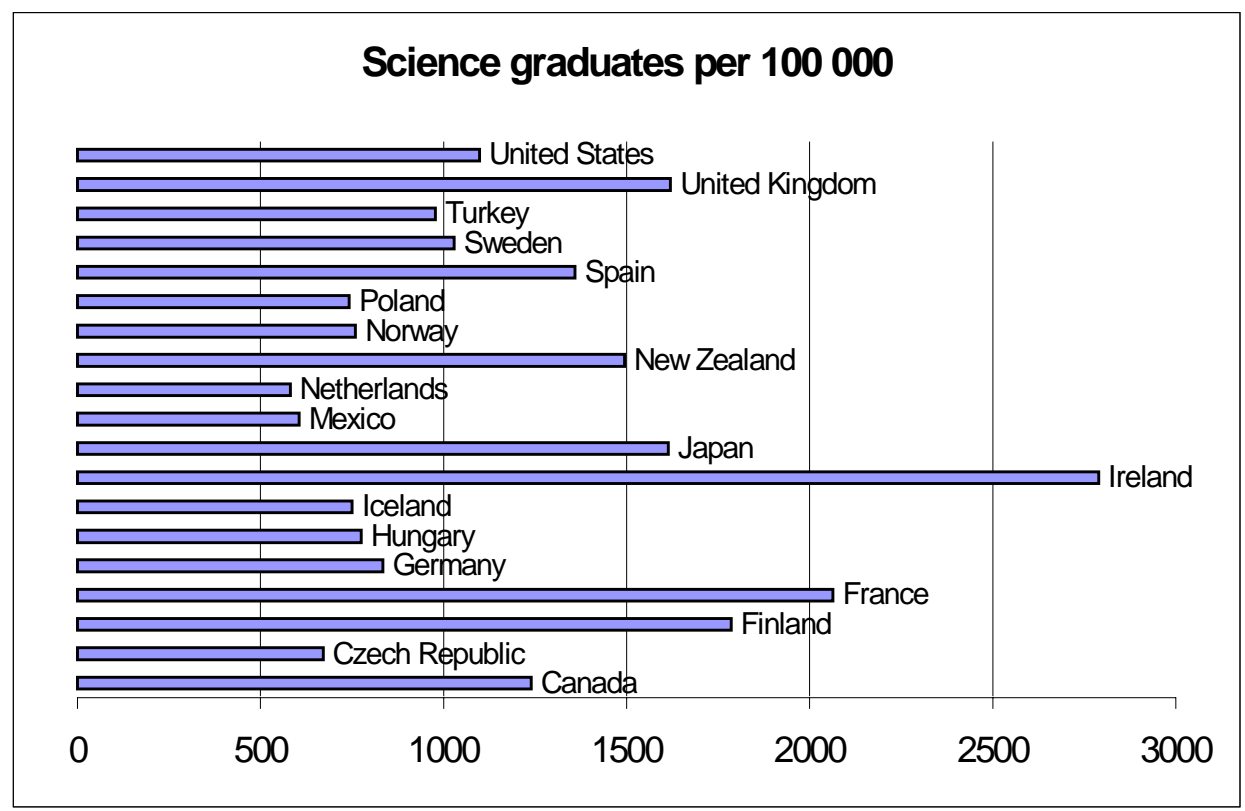

Source: OECD (2001a, p. 172).

Notably, this statistic is very weakly related to total expenditures on tertiary education; the correlation is 0.04 (expenditures from OECD 2001a, p. 81).

As surveyed by Temple (2001), empirical estimates of the private monetary return to schooling typically are in the range between 5 percent and 15 percent (depending on time and country), and the positive correlation between schooling and earnings is robust and uncontroversial. $\mathrm{A}$ different way to measure the returns on education is to use macroeconomic variables. Temple (2001) also surveys this literature. According to these results, about 0.1 to 0.5 percentage points of annual growth can be attributed to improvements in labor quality.

3 There are some cross-country comparisons of basic skills that may throw light on some aspect of the stock of human capital with particular reference to Sweden. It seems that the relatively large amount of resources spent on primary (and secondary) education in Sweden pays off in terms of literacy. In a comparison of 12 OECD countries 1994-95 (OECD 1999, ch. 2) Sweden had uniformly the best literacy levels across age groups. Looking directly at scores obtained at a literacy test, Sweden ranked uniformly first across education levels. The record seems less unambiguously favorable as regards achievements in mathematics. In a test of 8th-grade students across all OECD countries, the average score among Swedish students was essentially equal to the mean; this is subject to some caution, however, since Swedish 8th-graders have one year less formal schooling than those in most other countries - this fact, on the other hand, seems noteworthy by itself. (There are findings indicating that mathematics is particularly important for labour-market success; see Björklund 2000.)

4 See also OECD (1997), Wright (1999) and Pereira and Silva Martins (2000).

5 Björklund (2000) estimates simple log-linear wage equations for Sweden finding that the return to an additional year of education was a 4.6 percent wage increase; he also, however, discusses a number of limitations of simple estimates, and cites (scarce) evidence of education subsidies impacting measured private returns strongly.

6 Strong effects are reported from Mankiw, Romer and Weil (1992), suggesting that doubling of investment in human capital yields an increase in output per worker by about 50 percent. However, 


\section{Motivations for public education}

As reported in the previous section, governments in all OECD countries carry out an active education policy. In order to evaluate this policy, it is important to understand why the government intervenes in this market for investment goods. There are several reasons for this public intervention, some of which address efficiency aspects, while others relate to distributional aspects.

\section{Equal opportunities and redistribution}

A point that is frequently made is the "equal opportunities" argument, according to which it is considered desirable to give access to education investment to all children, regardless of the wealth, social status or education of their parents. The desirability of equal opportunities could be justified by normative equity considerations as well as efficiency considerations. If there is heterogeneity among individuals with respect to their ability to turn education investment into earnings or output, it would imply a loss in efficiency if only the children of the rich have access to human capital investment opportunities since the rents from investment for children of poor parents with high returns on human capital investment would be lost.

Access to human capital investment is often restricted. First, children of poor parents may be unable to finance their university education by a private loan due to imperfections in the private credit markets. The government could open the access for this group of children by student loans, and by public provision of free university education. Second, and related to this, investment in human capital is a risky business. If there are no private markets for diversifying these risks, the government may step in and provide insurance by sharing in the investment cost as well as in the returns from the investment via labor income taxation. This second consideration has been the basis of much theoretical analysis (see, e.g., Eaton and Rosen 1980, Varian 1980, Hamilton 1987, and Anderberg and Andersson 2001). Third, there may be an inefficient allocation of information about human capital investment opportunities, with children of parents with a superior educational background having superior access to information; this may cause some inefficiencies.

Empirically there is a strong link between parents' education and their children's education investment. This has been shown, for instance for the U.K., by Ermisch and Francesconi (2001), for Sweden in Högskoleverket (1997, pp. 45-47), and for Germany, by Grüske (1994, p. 95n). Erikson and Jonsson (1996, ch. 1) scrutinize the evidence concerning the achievement of equal opportunity more broadly from a mainly sociological perspective, "equal opportunity" meaning, essentially, that the educational distribution is independent of origin. Erikson and Jonsson conclude that while there are a number of factors that appear to promote equal opportunity (generally equitable living

Temple (2001) also surveys the discussion that explains that these figures may strongly overestimate the effect. 
conditions being one such factor), there are only a few factors that have a clearly discernible favorable effect. The two most important such factors are the elimination of early decision points for students (contrary to some intuition, students' choices are more sensitive to their background early on), and the elimination of "dead ends" in the education system, i.e. elimination of lines of study that do not qualify for continuation." Moreover, Erikson and Jonsson point out that a meritocratic system - i.e. a system which is selective with selection based purely on merit rather than involving subjective evaluations - on the whole tends to promote equal opportunity in the sense described. As to the effect of incentives on equal opportunity, this is a more controversial matter; Sjögren (2000) builds a model where a student's uncertainty about their ability in a particular occupation is larger the larger the "distance" from parental occupation. She estimates the model on Swedish data, confirming the model prediction that students from poor backgrounds are more sensitive to economic incentives for education. Erikson and Jonsson (1996) also consider the evidence concerning the effect of incentives, and conclude that there is evidence in both directions.

In order to assess these arguments as a basis for governmental intervention from an efficiency point of view, one needs to analyze the reasons for the constraints, and ask why the government could do better than the market.

A virtue of standard education policy is that it enables individuals who are credit constrained - i.e. individuals who are unable to finance their investments in the credit market - to make investments in human capital. This notion has received considerable attention in development economics (see e.g. Aghion and Bolton 1997) and it is clear that credit markets are far from perfect due to asymmetric information and incentive problems. The government influences the market outcome by a number of regulations, in particular between borrowers and lenders. For instance, high minimum income guarantees and regulations that shift the burden of individual bankruptcy away from the borrower to the lender or to society are clearly beneficial from an ex-post view. High minimum income guarantees yield insurance, and bankruptcy regulations that waive individual debt after a short time period have nice incentive effects for starting to earn income again for those individuals who have become bankrupt and are locked in a poverty trap otherwise. From an ex-ante point of view, however, minimum income guarantees reduce the available collateral in lending relationships, and bankruptcy laws that make it easy to leave the state of bankruptcy generate moral hazard incentives and may reduce or eliminate the scope for private market arrangements. For these considerations, the scope for government action on credit market constraints and the non-existence of private insurance markets is limited.

The answer regarding whether the government can really improve upon a laissezfaire outcome, depends on what causes the market imperfections and credit constraints.

7 Recent work by Meghir and Palme (2001) - employing a rather rare instance of a natural experiment produced by the gradual introduction of the Swedish comprehensive school in the 1960's - corroborates this idea; the elimation of a "dead end" in the old system changed the distribution of education obtained significantly. 
If education activity and the use of subsidized education goods are unobservable, the general insights in Arnott and Stiglitz (1986) on moral hazard in insurance markets apply: in many cases the government can indeed improve upon the laissez-faire moralhazard equilibrium by a mandatory scheme by which lump-sum financed education goods are subsidized or provided for free to all individuals.

Credit market constraints and the information advantages of children with parents with above average education may provide a clear basis for some education policy on redistributional grounds. Actual education policy, however, does not deliver the type of redistribution that is desirable from an "equal opportunities" point of view. Given that the percentage of children that takes up a university education is positively correlated with variables like parents' status or income, the present system is redistributive, but it redistributes on average more to families with rich or highly educated parents than to poor families.

If education investment is a transfer from parents to children, then intergenerational aspects must be considered. Suppose the transfers are motivated by altruism. Given the strong correlation between parents' income and educational attainment and their children's educational attainment, public funding of university education is a redistribution from poor parents to rich parents. The redistributive impact is further increased if one takes into account the fact that in-kind transfers of education goods have to be used by rich parents to overcome a Samaritan's dilemma problem that is faced particularly by rich parents if they are altruistically linked with their children, as has been pointed out by Bruce and Waldman (1991).

8 The intuition why the government can do what private insurance companies could not do in a competitive laissez-faire environment is as follows. Suppose an individual could purchase an education good that increases the probability of becoming highly productive, say, a book. Suppose that, from a welfare point of view, it would be beneficial if this book is purchased, because its cost are smaller than the expected human capital value it generates, but that this book is not purchased in the laissezfaire moral-hazard equilibrium with competitive insurance markets. The government can charge a lump-sum tax from everyone and hand out the book for free to overcome this problem. An insurance company cannot do the same thing because nothing prevents the insured from re-selling the book to someone who has purchased no or less insurance coverage from another insurance company that does not use a contract that includes the purchase of the book.

9 Another aspect of this argument is the social Samaritan's dilemma problem (see Bruce and Waldman 1991). If children have to finance their education investment and have to pay back a loan (whether this is a private loan or a public loan only makes a gradual difference with this problem), then it may be individually rational for the children to use up the loan and to stay below a critical income level at which repayments of the loan would start during their professional life, if such a critical income level exists (it exists in all welfare societies). One theoretical way to escape from this problem is to abolish or lower the critical income level. But this policy conflicts with the goals of a welfarist society. Alternatively, the educational grant could be made unconditional. This policy requires that there are other sources of government revenue that could be used for funding such a policy, but given the welfare losses that can be generated by the hold-up problem that is described by this Samaritan's dilemma, this cross subsidization may be worthwhile.

10 If parents are altruistic and sufficiently rich, children may abstain from education investment in order to elicit an increase in transfers and bequests from their parents. This outcome is inefficient, and inkind transfers to the children, like payment of tuition fees, can solve the dilemma. There is no strategic behavior that could induce huge bequests from poor parents, and rich parents thus have an additional incentive to provide education to their children that poor parents do not have. A publicly pro- 
If the ajm of education policy is redistribution according to an equal opportunities argument ${ }^{4}$, one may re-consider its targeting. We will briefly discuss an education policy that could improve targeting. The policy is based on the idea of self-selection and has been outlined, for instance, by Besley and Coate (1991). A person can, at a given time, consume only one type or quality level of education. For instance, the consumption of an undergraduate program in some discipline at a public university without tuition fees, and a similar program at a private university with high tuition fees are mutually exclusive. Suppose that the government decides to provide free public education on the university level and chooses a low or intermediate quality level (e.g., large classes, few teachers per student), and finances this program by a per-capita tax. Then poor parents and rich parents both have to make a decision whether to send their child to the tuition-free school, or whether to spend high tuition fees for an outstanding program. If university education for their children is a normal good, the population will be divided along income lines: the poor will prefer the tuition-free program, whereas the rich will not make use of the tuition-free program. Instead, they will send their children to the very top private schools, even though this implies paying high tuition fees. As a result, the poor and the rich jointly finance the tuition-free programs, but only the poor use it. Accordingly, some equalizing income redistribution can be achieved. Note that the government does not need to distinguish between poor and rich parents to make this work. It is the self-selection by which the rich decide to abstain from using the publicly provided programs that brings about the desired income redistribution.

\section{The returns to education and external effects}

Empirical estimates of the returns to education were provided in section 1. For an assessment of education policy one needs to ask whether the total return to education is higher or lower than the private return. According to Temple (2001, p.10), given the state of the art one cannot decide whether education investment generates these returns through productivity increases, or through signaling and information processing on existing productivity differences. Note also that both types of achievements have private and social benefits such that this question is not decisive for whether the public returns of education exceed or fall short of the private returns. Elementary education, language skills, writing or reading skills, foreign language skills, and more recently computer skills are important for the functioning of communication, and they are therefore potentially associated with network externalities. Similar arguments may be used for skills stemming from advanced education, such as a common cultural or intellectual back-

vided university system can crowd out these private incentives. There is evidence that the relationship between social background and labour-market success gets weaker with higher education (Erikson and Jonsson 1996, pp. 45-46); such a relationship is in accordance with this argument.

11 It is a legitimate question whether the existing types of education policy are designed to bring about redistribution from the rich to the poor, or to provide equal opportunities, or whether their distributional implications are on purpose. As is discussed in Epple and Romano (1996), the political economy outcome has a tendency for redistribution from the ends of the income distribution towards the middle. 
ground ${ }^{[2]}$ The relevance of such network externalities is probably more pronounced for elementary education (reading, writing, basic mathematics), and also relevant for some intermediate (secondary) education. For tertiary education the relevance of network externalities is probably rather limited, and free university education should probably not build on this type of argument.13

An important external effect of education goods has been emphasized by the modern theory of endogenous growth. (See, e.g., Lucas 1988). The corner stone of this theory is that investment in capital generates returns, but only some of these returns can be appropriated by the owner of the investment. Some of the returns "spill over" in a very dispersed way across the whole economy. But if only some fraction of the benefits of an investment is internalized in the decision of the investor, then underinvestment results. Accordingly, the economy suffers from underinvestment, and this is where governmental intervention may have its role. ${ }^{415}$ The relevance of this argument depends on whether such macroeconomic spillovers of investment exist or not, and if they exist, how important they are. It is difficult to distinguish from a theoretical perspective whether such spillovers result primarily from human capital investment, from spending on research and development, or on other investment activities, such as investing in physical assets, and empirical analyses do not reveal particularly unambiguous results.

\section{Sectoral neutrality}

Investment in human capital is only one of many alternative types of investment. In a laissez-faire economy, the various types of investment are used up to the point where they have the same marginal return. In a welfare state the various types of investment are typically distorted by taxes and regulations. These distortions of human capital investment may provide a second-best argument for public education policy.

Many Nordic countries (e.g., Norway, Sweden, Finland, and with modifications Denmark) tax the returns of different types of investment differently. Instead of following the principle of global income taxation that sums up all sources of income and subjects it to a uniform tax schedule, a dual system taxes capital income from ownership of physical assets at a lower rate than labour income; returns from human capital are part

12 For a formal analysis of such network effects of, for instance, language skills, and the resulting inefficiencies, see, for instance, Konrad and Thum (1993).

13 Gradstein and Justman (1999a, 1999b) consider similar externalities, claiming that education has a "socializing" function. If the education system is fully privatized, the outcome might be a less homogenous society with fewer common norms and value judgements. They argue in line with the theory of network externalities in Gradstein and Justman (1999a) that education can integrate a society if the education system is appropriately designed, and that to achieve this needs government intervention. Parents do internalize only some part of the benefits of a higher degree of integration; that is, they take into account that integrating their own children benefits them, but they disregard that this also benefits the rest of the society. Accordingly, a fully privately designed education system may provide too little integration. While this is an interesting idea, it is mainly an argument for government intervention in the design of education, and not necessarily an argument that concerns the question whether education should be privately or publicly funded.

14 See, for instance, Glomm and Ravikumar (1992) and Eckstein and Zilcha (1994).

15 Further external effects occur with the education system. See, e.g., Epple and Romano (1998). 
of labor income. Hence, the marginal tax rate on the returns of human capital exceeds the marginal tax rate on capital returns.

Nielsen and Sørensen (1997) argue that investment in human capital is not discriminated against, despite this fact. Whereas taxed earnings (savings) are typically the source of physical investment, a major share of human capital investment is generated from diverting leisure towards education effort. This leisure is an untaxed source of income. They conclude from this that there are tax advantages in human capital investment, and these tax advantages counteract the distortionary effect of higher marginal tax rates on the returns of human capital, compared with physical capital.

Exactly the opposite result is obtained in an analysis by Nerlove, Razin, Sadka and von Weizsäcker (1993). They assume that the same (taxed) input is used to make investment in human capital and investment in physical capital. They conclude that human capital investment is discriminated against due to differences in depreciation allowances. Both physical assets and human capital depreciate. However, whereas depreciation of physical assets reduces taxable income, the depreciation of human capital is not (or very partially) accounted for in the tax laws.

Given these two countervailing effects, the question whether actual laws discriminate more strongly against investment in physical assets or investment in human capital, cannot be decided easily. However, the analysis shows that there is some distortion between the inputs into human capital formation. We should expect that the input mix between time used for education, and (monetary) resources that are spent for education goods, is inefficient; a substitution of time by monetary effort is likely to improve welfare. As it may be difficult for the government to measure and observe actual monetary or time effort, it must rely on second-best tools like co-financing goods that are complementary with education.

This insight has some implications. It suggests that an efficient education policy should change the private cost of different education inputs differently. Monetary inputs in education should be subsidized relatively more than time use. It could also be useful from this perspective to have requirements on maximum time periods for achieving certain education goals.

\section{Government failure}

Human capital investment returns are taxed heavily. The maximum marginal tax rate on labor income in OECD countries was 50.2 percent on average in 1998. New Zealand had the lowest top marginal rate (33 percent), and Belgium had the highest rate with 66 percent (see OECD, 2001b). Boadway, Marceau and Marchand (1996) apply the idea of time consistent capital income taxation by a benevolent government that was formulated by Kydland and Prescott (1980) to human capital investment. Human capital investment

16 This point had been made already by Kaplow (1993). The inefficiency in the input mix does not imply that the absolute amount of time used in the production of human capital is too high. Given the various distortions at work, there may well be underinvestment in the sense that more monetary inputs and more time should be used in the production of human capital. 
is made when individuals are young. Its returns accrue 10 to 40 years later. Any investment made is sunk at the point when the taxes on human capital returns are decided. Individuals in their thirties, in midst of their working life, cannot react to high marginal taxes by a reduction in their human capital investment. A government that aims at efficient taxation and that wants to minimize the welfare losses from tax-induced substitution effects knows that the tax rate on human capital returns does not distort human capital formation at the time when the actual tax is chosen, because human capital investment is already chosen and sunk at that point in time. Accordingly, the government chooses a high tax burden on the returns from the existing stock of human capital.

Individuals anticipate this type of tax policy already when they make their human capital investment decisions. The high expected tax burden is a disincentive for human capital investment at this time when this stock of investment is still endogenous. Time consistent tax policy therefore yields high tax rates on the returns from human capital, too low education investment, too small a stock of human capital, and possibly little tax revenue. Time consistent tax policy results in a situation with excessive taxation and underinvestment in human capital. The government would be better advised to follow a commitment strategy in which it commits to a tax policy for the next few decades. It would commit to lower tax rates than the ones that are ex-post optimal in a time consistent framework. Human capital investment would be higher, and even the governmental tax revenue could possibly be higher than in the situation with anticipated time consistent excessive tax policy.

The central question is how to achieve an appropriate degree of commitment that can avoid the welfare cost of discretionary time consistent governmental behavior. This commitment problem is particularly severe; it requires that the government credibly commits to tax rates for the next 30 to 40 years, knowing that these desirable tax rates are much lower than the tax rates that the government would actually like to choose 30 or 40 years later. It can be doubted that commitment is feasible for such a long time period.

Boadway, Marceau and Marchand (1996) offer a solution: they suggest mandatory education, or, perhaps more appropriate for tertiary education, subsidized public provision of education. Governmental intervention is caused here by another governmental intervention. Public subsidies are not a means for curing a market failure, but they cure a government failure.

17 There is an intimate relation between the time consistency issue regarding redistributive taxation, and the appropriate education policy. One may want to redistribute via the provision of education goods ex-ante, and generate an environment with equal opportunities at the education stage. But if the success of education investment is to some extent stochastic, there may be scope for redistribution even if, at some point in time, all individuals were in a situation with equal opportunities. We will not pursue this line of arguments here, however.

18 Several solutions to the government failure of excessive time consistent taxation of human capital returns have been proposed in other contexts, but none of these solutions seems to be suitable for time periods of 30 years. Two types should be mentioned. Kehoe (1989) suggested that international mobility of tax bases and tax competition can substitute for the ex-post inelasticity of the tax base, limiting the scope for excessive taxation. We will come back to this when considering the issue of global- 
The same incentive problems appear for a Leviathan government that aims at maximizing the tax surplus, net of public investment. If a dictator, or a small power group, extorts a country and maximizes the surplus that can be extracted from extorting the country, any expenditure this group makes in terms of investment that enhances the country's output and prosperity in the future, is similar to the private investment by the owner of a company. This analogy has been pointed out by Olson (1993) and McGuirre and Olson (1996) more generally. The dictator of a country who earns returns from governing the country today may consider how much to invest in the country. The investment increases the output and productivity of the country which he extorts, and he will be able to appropriate a share of the increase in output that is generated by the unit of investment. The dictator will invest up to the point where the sacrifices of the unit of investment which he gives up for investment equals the benefits from the share of the increased output which he can appropriate. Hence, his investment incentive is higher the higher is the share of the marginal returns from investment which the dictator can appropriate. As long as the share of marginal returns which can be appropriated by the dictator is smaller than 100 percent, the dictator will invest too little.

Andersson and Konrad (2000b) show that a dictator and a benevolent government that would like to collect and redistribute taxes face very similar time consistency problems of income taxation. A revenue maximizing dictator would then have similar incentives to use education subsidies as a second-best tool to cure this problem.

\section{Globalization}

International mobility of production, inputs, consumption goods, information, knowledge, skills, and individuals has increased recently. In this section we consider the impact of this trend for tertiary education. Two main aspects will be highlighted. First, increased mobility generates fiscal externalities. These fiscal externalities have incentive effects for the amount and type of public and private education and tax policy. Second, increased mobility changes individuals' exposure to risk and their risk management tools. But before we turn to these policy aspects we consider some empirical aspects of skill mobility; while this is not the only type of mobility with implications for tax and education policies, it is the one with most direct such implications.

ization. Konrad (2001) discusses rents from asymmetric information on the actual productivity impact of individual human capital investments as a means to reduce the welfare effects of excessive time consistent taxation.

19 Konrad (1995) follows a similar argument with respect to an economy with overlapping generations in which the old generation is in power and extorts the young generation by means of a pay-as-you-go financed social security system on the one-hand side, and provides output-enhancing public infrastructure and education investment on the other. 


\section{On the significance of skill mobility}

We would expect skill mobility to be increasing for a number of reasons. For instance, in Europe, the common market with free mobility of factors, goods and people has been advanced in 1992. Portability of social insurance entitlements for workers who migrate between different European countries has also been improved. In addition, the world has moved closer together by a number of developments. International trade has grown, and many consumption products - including music, movies, and even television series have been standardized worldwide and have become universally available.

To assess international skill mobility empirically, turns out to be difficult however. A comprehensive effort in this direction is the work on Nordic skill migration by Pedersen, Røed and Schröder (2002).

It is often presumed that people with more education are more prone to migrate internationally. There are some obvious reasons for this presumption. It seems, for example, clear that education directly or indirectly makes people acquainted with foreign countries and foreign culture; language skills, of course, is an obvious case in point. It also seems clear that the fact that a higher degree of specialization coming with a higher education calls for searching a larger labor market; specialized skills in science, academia or engineering may be demanded only by a small number of employers in a country. There are, however, potentially countervailing forces; Röed (1996) points out that firm-specific skills may grow more rapidly for workers with more education, creating a stronger tie with the current employer. One can also argue that asymmetric information regarding skills is increasing in the skill level, and that it is therefore more expensive for high-skill workers to signal their skills to a foreign employer rather than a domestic one.

Empirically, the work of Pedersen et al. (2002) shows for the countries considered Denmark, Norway, and Sweden - that migration is considerably higher for workers with more education. This may suggest that they are more mobile; also it seems clear that these are the workers most susceptible to wage incentives.

Concerning the magnitude of emigration from the countries considered, Pedersen et al. find that it is quite small, and that return migration moderates the likely impact of emigration of skilled workers. Nevertheless, they find, for example, that net emigration from Sweden of some key categories of workers has been significant recently (table 5). Thus, while it seems clear that migration is relatively small, this is subject to a number of caveats. First, the significance of even a small increase of emigration would be substantial if those emigrating were to return to a lesser extent than is historically the case, and the extent of return migration is not observable until some time after emigration has

20 Of course, considerable obstacles remain and will remain given that social security systems in Europe differ along many dimensions (e.g., size, links between contributions and benefits, redistributional elements, or types of funding). However, the progress that has been made in the EU already is remarkable.

21 A discussion of empirical problems and a survey of some facts that support the hypothesis of increased mobility is given in Wildasin (2000a). He concludes that labor mobility has increased in Europe within the last decade, but that mobility is far from being perfect. 
taken place. Second, equilibrium migration is not a good indicator of potential migration. The fact that migration of skilled labor within Europe is small may be due to intrinsically low mobility, or to relatively weak incentives. It is therefore very hard to predict the effects of stronger incentives and reduced institutional impediments to migration.

These caveats are important in light of the fact that a number of impediments to skill mobility are subject to attack by the EU. There are efforts, for instance, to facilitate portability of social benefits and to standardize university exams. Moreover, the dramatic increase in student exchange among EU countries may be significant. The combined effect of exam standardization and student exchange is interesting: One potential problem for highly-educated workers is the lack of information a foreign employer may have regarding the worker's qualifications; reducing this informational asymmetry may serve to remove a substantial impediment to international skill migration. ${ }^{2}$ Such considerations open up for the possibility that the combined effect_of various aspects of globalization and harmonization may have sizable consequences.

In what follows we consider the implications of increased labor mobility, particularly, the increased mobility of highly skilled workers, and the incentives this increase in mobility generates for private and public incentives for human capital investment.

\section{Education and taxation}

With high labor mobility, the public benefits of higher education do not always accrue where education is funded. Justman and Thisse $(1997,2000)$ point out that this may undermine existing frameworks for funding public higher education, reducing the local incentives for provision of public education. In their framework, they assume that education is publicly provided and funded by the owners of a factor that is complementary to skilled labor. If labor reacts to wage differentials, a region can attract skilled labor by reducing its own level of public investment in education. They conclude that in the uncoordinated Nash equilibrium there is public underinvestment in education. A related mechanism is explored in Poutvaara and Kanniainen (2000). Here the unskilled cofinance public education and are better-off from this because skilled and unskilled labor are complements. Again, introducing international mobility of the highly skilled generates free-riding incentives: the financing share of the skilled cannot be sustained, and an inferior outcome results.

22 A model analysing such information asymmetries can be found in Katz and Stark (1987).

23 In addition, as pointed out by Pedersen et al. (2002), the growing pool of university graduates is manifest in the fact that emigration in the 90s has grown, while propensities across levels of education has stayed relatively constant.

24 In Gradstein and Justman (1995) international mobility generates an incentive to overinvest. The idea here is similar to Keen and Marchand (1997) who consider infrastructure competition for foreign direct investment: if foreign direct investment is internationally mobile, regions can attract more foreign direct investment if they offer a skillful labor force. In an uncoordinated Nash equilibrium overinvestment in infrastructure/local human capital occurs. 
Human capital mobility has also been considered in the tax competition literature. The increase in international mobility of highly skilled workers is an additional constraint for national tax policy. This insight is well established and clearly illustrated by Cremer et al. (1996). These authors discuss how robust the effects of the additional constraint are, given different institutional assumptions, and survey the extensive literature that considers this effect. They find that the mobility of human capital (that is, mobility of the highly skilled workers) reduces the scope for redistributive taxation.

Wildasin (2000b) has explored the interaction between the financing of humancapital investments in an imperfect credit market and globalization. The setting is one where education produces specialized skills. Unskilled workers are intersectorally mobile and geographically immobile; skilled workers are intersectorally immobile and globalization makes them geographically mobile. Globalization has the benefit of reducing the wage risk of high-skill workers. Wildasin compares the case where the education investment can be financed privately with the case where it cannot. The key conclusion is that whereas globalization is unambiguously beneficial in the former case, it leads to low-skill workers carrying the entire cost of education in the latter case. While obviously extreme due to extreme mobility assumptions, the result is in line with a recurrent observation in this context: the timing of education subsidies makes mobility of skilled labor very costly for immobile workers. Also, the trade-off concerning education investment when education is publicly financed is very harsh - education is productive but very costly due to the fact that its cost must be borne by low-skill workers.

The result in Justman and Thisse $(1997,2000)$ rests on the assumption that education investment has to be publicly provided and funded for exogenous reasons. However, education could be the instrument that counteracts the government failure of time consistent and excessive taxation. Suppose that international tax competition with respect to human capital income really takes place. If the highly skilled are perfectly mobile, the equilibrium tax rates in all countries are very low; in general term, faxes reduce to pure equivalence taxation and redistribution ceases to be feasible. Accordingly, there is no excessive taxation in the equilibrium in the globalized economy, and

25 Whether these effects are of practical relevance depends on whether the mechanisms that are described in the theory of tax competition are at work or not, and this question is closely related to the question of whether the highly skilled have become or will soon become highly mobile. Empirical analyses of tax competition problems exist with respect to a number of issues. However, the outcome of this empirical work is often ambiguous. While the outcome is typically in line with the predictions of tax competition theory, there are several other plausible and competing hypotheses that could explain the data similarly well. See, e.g., Brueckner (2000) for a survey.

26 Taxes used for public-good production might attract mobile factors if those factors benefit from the public goods in question. In fact, some empirical work on factor mobility indicates that infrastructure is more important than taxes for localization decisions. The basic point is made by Wildasin (2000a); the latter point is made by James Markusen in a comment published in Wildasin (2000a).

27 An important observation is that education subsidies although not always redistributive are likely to be subject to downward pressure from globalization because of their timing properties: Although a high-skilled worker considering the possibility to migrate internationally likely has benefited from education subsidies in his country of origin, this does not constitute a reason to stay. 
therefore no need for an education policy compensating for excessive taxation. ${ }^{0}$ For an extended analysis of the education-investment incentives of workers as well as governments in a scenario where education makes workers highly skilled and mobile, see Andersson and Konrad (2000a,b).

\section{Insurance aspects}

Seen from the perspective of individuals who do not know yet whether their human capital investment will make them rich and successful or poor and unsuccessful, redistributive taxation has features of an insurance policy. Time-consistent taxation in a closed economy will provide too much insurance, however, and thereby provide too weak (second-best) incentives for human-capital investment. If the public sector retreats from this insurance activity there will be a demand for private insurance. Whether and to what extent insurance markets will emerge is an interesting aspect of globalization. The answer depends on the extent to which insurance provided by redistributive taxation has crowded out private insurance that would have existed in the absence of such taxation; the viability of such markets will obviously depend critically on the way informational problems on those markets are resolved.

In the setting considered by Andersson and Konrad (2000a) where the investment in human capital is risky, and where globalization undermines redistributive taxation and leads to all education subsidies ultimately being borne by low-skill workers, the welfare effects of globalization depend critically on the possibility for workers to insure the outcome of their investment ex ante. If such income insurance is available, globalization is unambiguously beneficial; if it is not available, welfare effects are ambiguous - there is overinsurance due to time-consistent taxation in the absence of globalization, and there is no insurance in the presence of globalization. It is clear, however, that unskilled workers fare badly under globalization without private insurance, and that the policy trade-off when the only policy instrument is education subsidies borne by low-skilled workers is very harsh.

An aspect that has to be taken seriously in this context is the interim period. If globalization was not anticipated by individuals who are now in their 50ths, they did not anticipate that redistribution will cease to exist once they reach this age, and they will not have bought private insurance. Hence, for this generation, unanticipated globalization will lead to a strong increase in inequality.

28 Kehoe (1989) was the first to notice that globalization may resolve the time consistency problem in taxation.

29 The same forces may be induced if skilled labor is immobile, but capital complementary with skilled labor is internationally mobile. If net rents from the production utilizing skilled labor and mobile capital are shared by workers and capital owners, the same logic applies.

30 The analysis in Andersson and Konrad (2000a) shows that risk spreading via redistributive taxation and private insurance markets are substitutes. Given the level of public risk sharing through redistributive taxation, the non-existence of private markets for such risks - such as private education loans that are paid back only in case of success - is not surprising. This non-existence does not prove that these markets would not exist if the government would withdraw from this insurance activity. 


\section{Mobility differences}

Different types of professions or individuals differ in their international mobility. Lawyers or tax consultants are typically less internationally mobile than are medical doctors, engineers, computer specialists, or investment bankers. A government can choose whether to treat different professions differently, with respect to education investment subsidies and with respect to income taxes (see, for instance, Thum and Übelmesser 2000), or whether to find a way to commit to treating mobile and immobile professions uniformly.

With discriminatory tax rules, taxation and tax competition yields a situation in which immobile professions face high tax rates, and mobile professions pay little taxes. Accordingly, there is a hold-up problem with respect to investment in education for immobile professions, and no hold-up problem as regards education investment in professions that are perfectly mobile since the private investment incentives in these professions are high. According to the insights obtained from analyzing the hold-up problem in the closed economy and from analyzing globalization, it is optimal to use public education subsidies as a second-best policy to counteract the problem of underinvestment in the immobile professions, whereas no active education policy is needed in professions in which workers are perfectly mobile. The situation is more complex if discriminatory education subsidies are not feasible due to, for instance, education not being sufficiently specific, and specialization for mobile or immobile professions occurring when some or all investment in education has already taken place. Similarly, discriminatory taxation is sometimes not feasible, for instance because it is ruled out as violating some basic egalitarian principles in taxation (e.g., "horizontal equity").

A recurrent observation when considering mobility differences is that a net fiscal burden can be imposed only on low-income earners if discriminatory taxation is possible and if high-income earners are perfectly mobile and low income earners are perfectly immobile. An implication of this is that an extortionary state would have to rely on immobile low-income earners as its main tax base. This fact generates an additional incentive for young persons to invest in human capital, and the relationship between productivity and mobility generates excess incentives for private human capital investment. An extortionary state that observes individuals trying to escape from taxation by investing in mobility enhancing human capital has an incentive to make it more difficult for the citizens to acquire such human capital, for instance by taxing such activities. These issues have been analyzed more closely in Andersson and Konrad (2000b).

31 In a tax competition framework, if countries can choose ex post between uniform taxation and taxation that differentiates with respect to mobility, there is a tendency to differentiate tax rates with respect to mobility (Janeba and Peters, 1999). However, countries may coordinate on uniform taxation rules, and tax competition may then occur with respect to taxes obeying these rules. Keen (2000) has shown that whether tax revenue is higher with uniform taxation or with differentiated tax rates, is surprisingly unclear; he presents the case where differentiated taxation generates more tax revenue. 


\section{Policy implications}

We identified several important reasons for government intervention in the market for education.

First, concerns for redistribution and "equal opportunity" arguments may call for education policies that overcome credit market constraints and inequities in the process through which people make educational choices. Current attempts to generate "equal opportunities" are at best partially successful, and a whole battery of measures may be needed to counter the tendencies of a persistently scewed selection of students into higher education; as we have noted, there is evidence that private incentives and a strong emphasis on excellence may be beneficial rather than harmful in this regard. Moreover, free provision of education goods and education subsidies may reduce moral hazard problems in education goods markets and markets for student loans. A 'caveat' in this context is that although perfectly well-functioning private insurance markets and perfect credit markets cannot be established, current governmental tax and education policy may partially be responsible for these market deficiencies and may have crowded out some of these markets. The government may be able do a great deal to facilitate the emergence of such markets by changing the set of relevant constraints.

Second, it is unclear whether current education policy is an efficient means of redistributing from the rich to the poor. If this is the implicit aim of public education, one may want to choose an education system with several quality levels in which lower quality levels receive higher subsidies; in such a system redistribution occurs on a selfselection basis. Such alternative types of redistribution mechanisms may become more important in a globalized economy in which the scope for redistribution in general is reduced.

Third, we have compared the private and social benefits of education investment and identified a number of external effects of education. This analysis suggests that there are positive and negative externalities of education and the overall balance of external effects is unclear. The balance is more likely to be positive for primary and secondary education, however, suggesting that these types of education should be subsidized more strongly.

Fourth, we have considered the interplay between education investment and taxation, and several conclusions follow. The analysis suggests that there is a fundamental distortion of the "input mix" in education; the costs of time inputs borne by students are deflated due to income taxation. An implication is that education policy should subsidize education goods other than the time input more strongly than the time input. This may justify strict requirements regarding the overall time, or the number of failed attempts in examinations, a student is allowed in obtaining a degree. It may also justify subsidies to physical assets that are used in education. Since students' time input is probably complementary to the other resources devoted to their education, this is a reason to emphasize quality rather than quantity in higher education. Further, we have argued that public education provision is partially motivated as a second-best tool for 
overcoming the hold-up problem that is generated by time consistent excessive taxation of human capital returns. Globalization eliminates the scope for excessive taxation and the need for this second-best tool.

Fifth, globalization has a number of implications for a nation's optimal tax and education policy. In general, globalization limits the scope for redistributive activities, and this may lead to lower taxes and less education subsidies. However, we may also expect a differentiation of taxes and education policy along the lines of differences in skill mobility for different types of education and different professions. Our overall conclusion is that globalization will put pressure on government funding, including the public budget for expenditure on higher education, but that the simultaneous downward pressure on the taxes of the returns to human capital is a countervailing force in terms of sustaining the level of investment in human capital. The tightening of goverments' budgets and the limits this imposes also on public expenditure on education, however, calls for governments to focus their effort on alternative instruments that help promoting the goals of traditional education policy. 


\section{References}

Aghion, P. and Bolton, P. 1997, "A theory of trickle-down growth and development”, Review of Economic Studies 64: 151-72.

Anderberg, D. and Andersson, F. 2001, "Investment in human capital, wage uncertainty, and public policy”, Journal of Public Economics (forthcoming).

Andersson, F. and Konrad, K.A. 2000a, "Human capital formation and globalization”, International Tax and Public Finance (forthcoming).

Andersson, F. and Konrad, K.A. 2000b, "Human capital investment and globalization in extortionary states", Journal of Public Economics (forthcoming).

Arnott, R. and Stiglitz, J.E. 1986, "Moral hazard and optimal commodity taxation", Journal of Public Economics 29: 1-24.

Besley, T. and Coate, S. 1991, "Public provision of private goods and the redistribution of income", American Economic Review 81: 979-84.

Björklund, A. 2000, "Education policy and the returns to education", Swedish Economic Policy Review 7: 71-105.

Boadway, R., Marceau, N. and Marchand, M. 1996, "Investment in education and the time inconsistency of redistributive tax policy", Economica 63: 171-189.

Bruce, N. and Waldman, M. 1991, "Transfers in kind: why they can be efficient and nonpaternalistic", American Economic Review 81: 1345-51.

Brueckner, J.K. 2000, "Welfare reform and the race to the bottom: theory and evidence”, Southern Economic Journal, 66: 505-525.

Cremer, H., Fourgeaud, V., Leite-Monteiro, M., Marchand, M. and Pestieau, P. 1996, "Mobility and redistribution: a survey", Public Finance 51: 325-352.

Eaton, J. and Rosen, H. S. 1980, “Taxation, human capital, and uncertainty”, American Economic Review 70: 705-715.

Eckstein, Z. and Zilcha, I. 1994, "The effects of compulsory schooling on growth, income distribution and welfare", Journal of Public Economics 54: 339-359.

Emmerson, C. and H. Reed, 2002, "Use of fees in the provision of public services in OECD countries", in: Anderson T. and P. Molander (eds), Alternatives for Welfare Policy, Cambridge University Press (forthcoming).

Epple, D. and Romano, R.E. 1996, "Ends against the middle: Determining public service provision when there are private alternatives", Journal of Public Economics 62: 297-325. 
Epple, D. and Romano, R.E. 1998, "Competition between private and public schools, vouchers, and peer-group effects", American Economic Review 88: 33-63.

Erikson, R. and Jonsson, J.O. 1996, "Can Education Be Equalized? The Swedish Case in Comparative Perspective", Westview Press, Oxford.

Ermisch, J. and Francesconi, M. 2001, "Family matters: impacts of family background on educational attainment”, Economica 68: 137-156.

Glomm, G. and Ravikumar, B. 1992, "Public versus private investment in human capital: endogenous growth and income inequality", Journal of Political Economy 100: 818-834.

Gradstein, M. and Justman, M. 1995, "Competitive investment in higher education: the need for policy coordination”, Economics Letters 47: 393-400.

Gradstein, M. and Justman, M. 1999a, "Education, social cohesion, and economic growth”, Discussion Paper No. 99-16, Monaster Center, Ben-Gurion University.

Gradstein, M. and Justman, M. 1999b, "Human capital, social capital, and public schooling", paper presented at the EEA '99 meetings.

Grüske, K.-D. 1994, "Verteilungseffekte der öffentlichen Hochschulfinanzierung in der Bundesrepublik Deutschland - Personale Inzidenz im Querschnitt und Längsschnitt", in Lüdeke, R. (ed.), Bildung, Bildungsfinanzierung und Einkommensverteilung II, Schriften des Vereins für Socialpolitik, N.F. Bd. 221/II: 71-147.

Hamilton, J.H. 1987, "Optimal wage and income taxation with wage uncertainty", International Economic Review,28: 373-388.

Högskoleverket (National Agency for Higher Education) 1997: “Årsrapport för universitet \& högskolor 1995/96" (Yearly report for universities), Stockholm.

Janeba, E. and Peters, W. 1999, "Tax evasion, tax competition and the gains from nondiscrimination: the case of interest taxation in Europe", Economic Journal 109: 93101.

Justman, M. and Thisse, J.-F. 1997, "Implications of the mobility of skilled labor for local public funding of higher education", Economics Letters 55: 409-412.

Justman, M. and Thisse, J.-F. 2000, "Local public funding of higher education when skilled labor is imperfectly mobile", International Tax and Public Finance 7: 247-258.

Kaplow, L. 1993, "Human capital and the income tax", National Bureau of Economic Research, Working Paper 4299.

Katz, E. and Stark, O. 1987, "International migration under asymmetric information”, Economic Journal 97: 718-26.

Keen, M. 2000, "Preferential regimes can make tax competition less harmful", mimeo. 
Keen, M. and Marchand, M. 1997, "Fiscal competition and the pattern of public spending”, Journal of Public Economics 66: 33-53.

Kehoe, P.J. 1989, "Policy cooperation among benevolent governments may be undesirable", Review of Economic Studies 56: 289-296.

Konrad, K.A. 1995, "Social security and strategic inter-vivos transfers of social capital”, Journal of Population Economics 8: 315-326.

Konrad, K.A. 2001, "Privacy, time consistent optimal labor income taxation and education policy", Journal of Public Economics 79: 503-519.

Konrad, K.A. and Thum, M. 1993, "Fundamental standards and time consistency", Kyklos 46: 545-568.

Kydland, F.E. and Prescott, E.C. 1980, "Dynamic optimal taxation, rational expectations and optimal control”, Journal of Economic Dynamics and Control 2: 79-91.

Lucas, R.E.jr. 1988, "On the mechanics of economic development", Journal of Monetary Economics 22: 3-42.

Mankiw, N.G., Romer, D. and Weil, D. 1992, "A contribution to the empirics of economic growth", Quarterly Journal of Economics 107: 407-437.

McGuire, M.C. and Olson, M.jr. 1996, "The economics of autocracy and majority rule", Journal of Economic Literature 34: 72-96.

Meghir, C. and Palme, M. 2001: "The effect of a social experiment in education", mimeo, UCL and Stockholm School of Economics.

Nerlove, M., Razin, A., Sadka, E., and von Weizsäcker, R.K. 1993, “Comprehensive income taxation, investments in human and physical capital, and productivity", Journal of Public Economics 50: 397-406.

Nielsen, S.B. and Sørensen, P.B. 1997, "On the optimality of the Nordic system of dual income taxation", Journal of Public Economics 63: 311-329.

OECD 1997, "Implementing the OECD Jobs Strategy: Member Countries Experience", Paris.

OECD 1999, "Human capital investment: An international comparison", Paris.

OECD 2000a, "OECD in Figures, Statistics on the Member Countries", Paris.

OECD 2000b, "Education at a glance: OECD indicators", Paris.

OECD 2001a, "Education at a glance: OECD indicators", Paris.

OECD 2001b, "OECD in Figures, Statistics on the Member Countries", Paris.

Olson, M. 1993, "Dictatorship, democracy, and development", American Political Science Review 87: 567-576. 
Pedersen, P., Røed, M. and Schröder, L. "Emigration in the Nordic welfare states", in: Anderson T. and P. Molander (eds), Alternatives for Welfare Policy, Cambridge University Press (forthcoming).

Pereira, P. and Silva Martins, P. 2000, "Does education reduce wage inequality? Quantile regressions evidence from fifteen European countries", IZA DP No. 120, IZA, Bonn.

Poutvaara, P. and Kanniainen, V. 2000, "Why invest in your neighbor? Social contract on educational investment", International Tax and Public Finance 7: 547-562.

Røed, M. 1996, "Education and international migration: Theoretical aspects", in E. Wadensjö, (ed.), The Nordic Labour Markets in the 1990s, part 2, North-Holland, Amsterdam.

Sjögren, A. 2000, "Occupational choice and incentives: The role of family background", Working Paper 539, The Research Institute of Industrial Economics, Stockholm.

Temple, J. 2001, "Growth effects of education and social capital in the OECD countries", mimeo, University of Bristol.

Thum, C. and Übelmesser, S. 2000, "Mobility and the role of education as a commitment device", mimeo.

Varian, H. 1980, "Redistributive taxation as social insurance", Journal of Public Economics 14: 49-68.

Wildasin, D. 2000a, "Factor mobility and fiscal policy in the EU: policy issues and analytical approaches", Economic Policy 31: 337-378.

Wildasin, D. 2000b, "Labor-market integration, investment in risky human capital, and fiscal competition", American Economic Review 90: 73-95.

Wright, R.E. 1999, "The rate of return to private schooling", IZA Discussion Paper No. 92, Bonn. 